\title{
Viewpoint
}

\section{Spontaneous Settlements in Turkey and Bangladesh: Preconditions of Emergence and Environmental Quality of Gecekondu Settlements and Bustees}

\author{
Shihabuddin Mahmud* \\ Department of Landscape Architecture and Urban Design, Bilkent University, \\ Ankara, Turkey
}

Umut Duyar-Kienast

Technical University of Berlin, Berlin, Germany

\begin{abstract}
Spontaneous settlements are common phenomena in many third world countries. Although the different geographical locations, along with morphological factors, play an important role in shaping up different physical settings, dynamic social factors have similar consequences in such settlements. Ankara's gecekondu and Dhaka's bustees are in continuous change and adaptation into the structure of the cities in which they exist. Both remain as popular housing in the respective capitals of Turkey and Bangladesh. The aim of this paper is to find similarities and dissimilarities among gecekondu and bustees, giving an emphasis to five fundamental issues. Those are location of the settlement within the city, appropriation of land and ownership patterns, economic possibilities of the inhabitants, cultural and local dynamics of formation and uses of space, and last, the transformation of the settlements. Despite all physical and social dissimilarities, ownership patterns are perhaps the key factor in the development of such settlements both in Ankara and in Dhaka. The main commonality is that those settlements provide not only shelter but also possibilities to satisfy other needs for their inhabitants. (c) 2001 Elsevier Science Ltd. All rights reserved.
\end{abstract}

Keywords: informal settlements; Ankara; Dhaka; comparative research

\section{Introduction}

Informal settlements, which are irregular in their physical settings and illegal in the appropriation of land and/or

*Corresponding author. Tel.: +90 312290 2255; fax: +90 312266 4053. e-mail: mah-

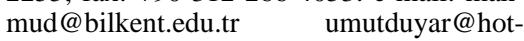
mail.com exploitation of building rights, are typical of the developing countries. They are results of the high rate of migration from rural areas into the big cities. Those migrants aim for a better life and better job opportunities. However, in urban areas there are neither enough jobs or proper housing waiting for them. Due to the lack of formal insti- tutions and solutions for their problems, they have to create their own way to survive in the city. They have to maintain relations among their relatives, which enables them to find a job and shelter. They build their own houses within a network of people having similar experiences. They use their own labor and local or second-hand 
materials in the construction of their houses. According to McTaggart (1988) the primary characteristic of a spontaneous settlement is its construction, essentially by the residents. The people of such settlements do not depend on the regular housing market but they act in an informal market with its own builders, suppliers and contractors, in which the owners also use their own labor and skills.

Although the appearance of such spontaneous settlements is different in each country, there emerge under similar conditions and they have some characteristics in common. Mainly, squatter settlements are places which enable their inhabitants to survive an urban life. While gecekondus and bustees have very different spatial characteristics, we argue that these settlements fulfill similar functions for their inhabitants. They are spatial manifestations of similar needs and appropriation processes which change in time and adapt new tactics in order to exist in the labor and housing markets and to get acceptance by the local authorities. We are going to bring out the commonalties in two examples of such illegal and spontaneous settlements in Turkey and Bangladesh, by studying their environmental context. The environmental quality of a neighbourhood enables it to fulfill a wide range of functions and gives clues about the social and economic structures there.

The concept of environmental quality in any settlement mainly involves the density, quality of materials used, physical infrastructure and civic services. But there exist other important issues. Those are variety, multi-functionality and flexibility of space, as well as the ability of the environment to satisfy human needs and to make the socialization possible. For example, the intensive use of public spaces enables people to interact and to help each other. The discussion of squatter settlements and their environmental quality can be classified under the following topics: (i) location of the settlement within the city, (ii) appropriation of land and ownership patterns, (iii) economic possibilities of inhabitants, ie occupation and income groups, (iv) cultural and local dynamics of formation and use of space, (v) transform- ation and growth potential of the settlements.

Ankara's gecekondu and Dhaka's bustee are ubiquitous in their presence in the respective cityscapes. Today, the rapid growth of these settlements has become a critical issue, as they are a dominant way of housing lower and low-middle income groups in both cities. Ankara's gecekondus have existed extensively since the 1930s and 1940s. ${ }^{1}$ Highly limited access to land for legal housing, the high cost of housing materials, coupled with the rapid growth of population mainly through the migration of the rural poor, have caused rapid proliferation of innumerable urban gecekondus. Although the emergence of such settlements has different backgrounds and conditions, there exists a common hope for a better living for these people and to integrate with urban life style.

Ankara was planned as a capital city with a population of only 300,000 by Jansen, a German architect and planner, mainly for bureaucrats and government officials. It would be an example of a planned modern city for the modernized elite of the republic. However, the urbanization process did not follow the estimates. Since the 1960s, more than half of Ankara's population live in illegally and informally built gecekondu settlements, mostly located on the fringe of the city. In 1990 the percentage of the gecekondu dwellers in Ankara's total population was $58.3 \%$ (Keles, 1993 cited by Özdemir, 1998, p 84). Official statistics provide little relevant information about the recent development of gecekondu housing in Ankara (or in any other cities in Turkey). However the State Planning Organization estimates the number of illegal housing to be around 2,000,000 in the three big cities, Istanbul, Ankara

\footnotetext{
${ }^{1}$ One of the important publications from the $40 \mathrm{~s}$ and $50 \mathrm{~s}$ is a series of interviews in a newspaper by Fenik, A. "Altindag Röportajlari”, Zafer, Mayis 1949 cited by Baydar Nalbantoglu (1998, pp 153-167). It gives information about the way of housing and living in the oldest gecekondu settlement in Ankara. Another study on gecekondu from 1950s is that by Ögretmen, I. Ankara'da 158 Gecekondu, Ankara: Ankara Üniversitesi Siyasal Bilgiler Fakültesi, 1957 cited by Tekeli (1996).
}

and Izmir (Eight Five Year Plan, 2000, p 172)

Dhaka, on the other hand, faced a number of different political phases. ${ }^{2}$ Dhaka City has been a capital off and on since the period of the Mogul Emperors. Dhaka was one of the important centers during British rule and became the capital of East Pakistan in 1947 when the British left. In 1971, after the formation of Bangladesh, Dhaka still was the capital and the most important economic and administrative center. Although bustees existed before the war in 1971, a massive migration towards the capital took place right after the war (Rahman, 1999). The population of Dhaka has been estimated as 7 million and 3 million of this population is living in varieties of bustees that spread all over the city (Gono Shahajjo Shansta, 1995). The most striking feature of Dhaka's bustee is its residential pattern; $70 \%$ of the city's population is forced to squeeze on to $20 \%$ of the city's residential areas (Islam, 1996).

\section{Location and the spatial distribution in the cityscape}

Ankara's gecekondus are usually on illegally subdivided land on the fringe of the city where there is steep topography. They are places that were never planned for development. These areas belong either to public institutions or to private owners. The land there is cheap because there are no building codes or any infrastructure. Gecekondus were originally homogeneous and compact,composed of physically similar housing units built with similar processes and occupied by low or lowermiddle income groups. However, since the second half of the 1980s, in some of those settlements apartment houses have appeared between houses, or some small gecekondu houses are placed between newly built apartment

\footnotetext{
${ }^{2} \mathrm{~A}$ comprehensive mapping of the physical appearance of bustee was conducted by CUS for ICDDR,B, Dhaka in 1990, under the supervision of Dr Nazrul Islam.
} 
houses. This follows a series of amnesty laws and Improvement Plans. ${ }^{3}$

Unlike gecekondus in Ankara, bustees can be seen anywhere in the city, both on unauthorized public or semipublic land or on the lands of private owners. They can also be seen in the vacant land in the most expensive areas of the city. In Ankara, the better transportation network ${ }^{4}$ with strong connections to the city center allows the gece$k o n d u$ dwellers to reside in the fringe areas. Whereas the bustee dwellers in Dhaka prefer to stay in near proximity of the center, as it is easy to get a job in the marginal sector and as they are not ready to spend extra money on transportation. However, a recent trend for bustee dwellers is that they are moving towards the periphery of the city to find shelter mainly on lands which are owned by private individuals. Today, $60 \%$ of the total lands covered by bustees are concentrated in the fringe area in Dhaka. ${ }^{5}$ Bustee settlements can be seen with different shapes and sizes and are usually rentals with very limited floor space. As most landowners wanted to profit from their vacant land, these settlements are distributed in a very irregular manner throughout the city. It is also evident

${ }^{3}$ Through the Amnesty Laws from 1983, 84 and 86 and Improvement Plans firstly introduced in 1983 (with law no: 2085) a transformation process of gecekondu houses into apartment houses and the provision of a basic technical infrastructure were foreseen in order to integrate these districts into the regular city. Usually the Improvement Plans proposed higher building codes and a redevelopment in those areas. So the problem have been solved by transforming the houses of the urban poor on squatted or illegally subdivided land into objects of speculation. As a result there occured some apartment-house districts or individual examples of this kind of transformation in previous gecekondu settlements on the rather rentable plots.

${ }^{4}$ Ankara does not have proper functioning public transportation. But a parallel development to the emergence and extension of gecekondu was the institutionalization of another transportation mode called dolmus. It consists of a whole fleet of small buses with fixed routs but flexible stops and schedule. It connects the settlements on the fringe of the city to the city centers.

${ }^{5}$ There are three resettlement areas of bustees which were built in 1975 and they are Vashantek (Mirpur), Dattapara (Tongi) and Chanpara (Demra) relocated on the outskirts of Dhaka City. that the peripheral zone of the city has a larger number of bustees compared to the inner zones. Bustees on the periphery are comparatively compact, contiguous and large and those in the inner city are mostly small and scattered at various locations, although in some areas a linear pattern has been developed, especially along the railway line and some roads.

\section{Appropriation of land and ownership patterns}

The word gecekondu means "constructed overnight". Actually gece$k o n d u$ houses are the result of a very complex squatting procedure and home building over a period of years, although the rough structure of a house is, in fact, built very quickly. The ownership pattern is also very complex. The land is either squatted by the occupants or squatted by unauthorized people and then sold. In addition, the Improvement Plans made after the amnesty of 1985 increased the complexity of the ownership pattern in gecekondu. The occupants get some kind of title confirming their ownership on land. This gives the inhabitants the rights of tenure on a building plot in the same area defined by the Improvement Plans, with new building codes. Mostly, they are gathered together with their neighbors into a new plot and their existing plots and houses are still illegal. Although gecekondu houses are mostly built for self-use, they have also an exchange-value in the housing market, as thus constitute social and economic security for their owners.

The definition of bustee is also ambiguous, as it is does not clearly tell anything about the ownership pattern. Usually bustees are constructed either on unauthorized government land or on the land provided by private owners. For the last two decades, making bustees on private land has become very popular, as bustee owners are private entrepreneurs who want to make money with a cheap investment and a high return, as there exists a tremendous demand for such housing. Moreover, in both cases (gecekondu and bustee) there exist some illegal components such as land Mafia's or Mastan (muscle men) who take regular "taxes" of protection money from such settlers (Huq-Hussain, 1996).

In most cases, the land in gecekondus is public land either bought from the previous occupants $(52 \%)$ or squatted by the current inhabitants $(34 \%)$. A smaller part of it is privately owned land (12\%) (Alpar and Yener, 1993, p 111). Most commonly, bustees flourished on land belonging to private individuals or households $(65 \%)$. A significant proportion of the settlements $(29 \%)$ were set up on government and quasi-government lands. These settlements are mostly squatted and they have developed land owned mainly by the Departments of Railways, Public Works and Roads and Highways. A small number of clusters $(3 \%)$ were constructed on disputed land (MOL/GOB, 1989).

In Ankara's gecekondus 28\% of homes are rental and $72 \%$ are owner occupied (Alpar and Yener 1993, p 108). The rent per unit of gecekondu does vary according to the location and proximity to the city center. Houses are generally owner occupied or a portion of the house may be rented out, whereas private bustees are mostly constructed for rental purposes. At this point, gecekondus are typically owner occupied and the quality of and investment in such settlements depends on the legal title of the land. On the other hand, construction of bustees on privately owned land has become a highincome business for many rich landowners in Dhaka, who are bustee owners but not bustee dwellers. In addition, rents per unit area of floor space in bustees can be sometimes higher than the housing areas of middle class in some areas of Dhaka. A survey conducted in Dhaka showed that a great majority of bustee respondents are tenants, as the poor migrants do not have the money to buy a bustee structure and have to be satisfied with the rented one. The only way to change or to shift to a better structure, with better facilities, is if their economic condition improves in time (Haque, 1989).

In both of the cases we observe a trend of commercialization and speculation. Therefore, access to the land for the urban poor is getting more difficult. The ownership pattern and security of tenure is very important, in that they determine the quality of the built 
environment. If there is no danger of being demolished by the officials of the local government, the houses can be built to a better condition, with stable materials over a longer period of time. The additional rental units in the houses help to increase the income of the family but if the owners do not live there, the area can easily decay due to the lack of investment and maintenance of the existing structure.

\section{Economic potential of the inhabitants}

The economic possibilities of both gecekondu and bustee inhabitants show similarities. The gecekondu dwellers in Ankara are usually low-income, and work in marginal services or the production sector or as unqualified labor in the administrative sector (Alpar and Yener, 1993, p 125). ${ }^{6}$ Senyapili (1983) addressed gecekondu women as a new commodity in the economic sector of a city, insofar as they usually bear two different identities, one as a domestic worker and another as an earning member of the family. However, the labor of women is perceived as gendered domesticity rather than productive work. Gecekondu women are mostly employed in the marginal service sector or in home-based activities and they do not call their income-producing activities “work" (White, 1996, pp 32-35). Eraydin and Erendil (1999) differentiate between first generation females and a new generation; the type of job opportunities also varies from city to city in Turkey.

Although female workers working as cleaning women or maidservants in upper or middle-income neighborhoods are common in both cities, construction and textile sector jobs are available to female bustee workers. In Dhaka, the bustee dwellers constitute most of the low-income population of the city as well. A big portion of the latter, (both male and female) works in the construction sector on a daily basis. Women work in home-based production and those who are little edu-

${ }^{6}$ Working sectors vary widely in different cities, like Istanbul, Ankara and Izmir. This reflects on the spatial structure and characters of the settlements in those cities respectively. cated also get jobs in the garment factories. It is obvious that gecekondu and bustee settlers have similar backgrounds which determines how they work in their respective cities. A large portion of the Bangladeshi male population works as a rickshaw $^{7}$ puller (tricycle) as it is well paid and also easy to get. The majority of male workers are involved in these irregular jobs. Vendors or hawkers (selling food or clothing) are the most lucrative job for men in the city centers. It has been noted that in any low-income settlement there is a tendency to see more earning members in the family and they may also have two or three occupations simultaneously. Although religious obstacles encourage the women to remain within their household, economic necessity forces them to come outside and work with the opposite sex in both cities. Using homes for income generation is both common in gecekondus and bustees.

In the regular housing market, it is impossible to find a solution for the housing question for the urban poor with an irregular income. The informal market, on the other hand, enables some possibility of credit for them. The craftsmen organize the purchase of materials and rates of payments for them as well as the size and plan of the house. The relatives and fellow countrymen (hempehri) help to get credit. In the end, with all these networks, the squatter settlements are not only a partial solution for the housing problem but they provide a kind of social security for their inhabitants. They are also the only possibility of finding accommodation for tenants with limited income.

\section{Formation and use of space}

The gecekondus and bustees differ in their physical outlook. Physically, gecekondus with their one or two storey structure, are more permanent when compared to bustees. However, in general, a bustee can be characterized as having kutcha (temporary) or semipucca (semi-permanent) structures,

\footnotetext{
${ }^{7}$ Rickshaw is the most popular transportation mode in Dhaka and alleviates the unemployment problem of the bustee people.
}

normally of a single storey. A small garden or courtyard can be seen easily within any gecekondu household but in bustees it may be a rare case. The residential densities of gecekondus are not as high as bustee; the former neighborhoods are more spacious than any middle income or upper middle-income settlement in Ankara City for instance. According to the study by Alpar and Yener (1993, p 116) $45 \%$ of the gecekondu houses in Ankara are between 75 and $99 \mathrm{~m}^{2}$ and the family size is approximately five persons. In addition, most of the gecekondus in Ankara have gardens or courtyards; mostly, 30-70\% of a plot is built up and the rest is left non-built. Therefore we can say that the density is almost 300-500 persons/ha. As more bustee means more return for bustee entrepreneurs, there can hardly be found empty open spaces in such settlements. Today, bustees can be claimed as one of the densest areas, 2471-6178 persons/ha (Islam et al, 1996). With regard to household floor space, a national report indicated that the average floor space per household in urban areas of Bangladesh is $109 \mathrm{~m}^{2}$ whereas it becomes $30 \mathrm{~m}^{2}$ for bustee dwellers (Huq-Hussain, 1996, p 100).

The physical shapes of gecekondus and bustees mainly differ according to the construction type and materials used. In both cities, locally made and cheap materials are preferred. In Turkey, the ardiye, ie specialized supply yards have an important role in the construction of gecekondu houses. They have been supplying, since the mid50 s, cheap construction materials, eg salvaged materials from the buildings demolished in the redevelopment process in the regular parts of the city (Payne, 1982, p 121). Bustees are mostly made of bamboo mat, tin and dry grass. According to a government report, $66 \%$ of the bustee houses in Bangladesh are made of poor construction materials. Another government survey indicated that nearly $18 \%$ of the bustee dwellers in Dhaka live in extremely poor housing termed Jhupri. ${ }^{8}$ About $38 \%$ of the bustee population

\footnotetext{
${ }^{8}$ The survey authority defined jhupri structure as one with a height lower than normal $(2.5-3.5 \mathrm{~m})$ and a roof made of pieces of tin, bamboo, straw, leaves or polythene sheet.
} 
live in bamboo sheds with normal height and a bamboo roof which is comparatively better than the jhupri, while $42 \%$ live in tin shed structures having normal height and a tin roof (Huq-Hussain, 1996, p 100). In contrast, the main material for a gecekondu is usually brick where the roofs are wooden with either tin or roof tile.

In the case of gecekondu areas, one can easily judge from the provision of municipal services whether or not it been recognized and is tolerated by the authorities. Water, sanitation and electricity are used by almost every gecekondu. In the first phase of emergence, infrastructure, especially electricity, is used illegally via precarious connections. The households do not have separate access to water. However, in the later phases of consolidation, they receive all these services and pay for them. In their study on the infrastructure provision Leitmann and Baharoglu (1999, p 205) also conclude that "access to basic infrastructure and services in gecekondus is generally good but there are problems with the affordability, quality and quantity of specific services". The environmental quality of illegal bustees, on the other hand is low, as they have little or highly inadequate provision of sanitation, pure drinking water or other utilities.

The sequence and the emergence of such settlements are based on similar factors. Both gecekondus and bustees are spontaneous in their development as they both are constructed and shaped according to the necessity of spaces for different purposes and this changes over time. Gecekondu houses do not have any plan and most of the time especially in the early examples - any long term goal of how the completed house might look. The spatial layout of a house changes according to the needs, financial possibilities and individual concepts. Gürcinar (1988) defines the spatial development of a gecekondu house in sequence. First of all a cellunit is built with a toilet outside of the living place within the garden. Then other rooms are added and the first room will be used as the entrance, as a small hall. The addition of other rooms depends on the economic possibilities and needs of the family, as mentioned above (Fig. 1).

The spatial structure of gecekondus is in continuous change, within very complex processes. The spontaneous additions on each plot bring an organic spatial structure for the whole settlement, at the end with 1 or 2 storey houses within gardens, irregular and narrow streets and cul-de-sacs. The emergence of a house with its garden is based on the relations among the neighbors, who are also often relatives. Power relations, for example that emerged within the hierarchy in the family, determine the density and the unique spatial structure, like the existence of small paths, short-cuts between the gardens, and so on.

Unlike this process, another way developing a neigborhood has been experienced in Aksemseddin Mahallesi, in early 1990s. It may be not typical but very interesting in that the changes in the strategies of gecekondu dwellers towards official interventions and political approaches of local administrative units and the state could be observed. This unique process of emergence of a gecekondu was organized by an individual man with political abilities and relations as well as his experiences as a former gece$k o n d u$ owner. He had a role like a contractor in building the houses, as well as organizing the squatting process on the land. They built their houses in a way that the settlement should already seem "finished" and "regular" at the beginning. The division of land and construction process were very well organized and "proper", as if it was a "planned settlement". Therefore the spatial structure of this settlement is different from those from early examples (see Fig. 2).

Gecekondu dwellers are rural migrants moving to urban areas. They are firstly settled as tenants in gece$k o n d u$ areas who probably later try to buy or occupy a plot for their own house. There is also the second generation of gecekondu inhabitants who built their own house - mostly in the garden of their parents - when they are married. In this process of settling in the city the most important help comes from the relatives, the land men and the circle of acquaintances. The inhabitants of a bustee come across a number of different shelters as they first move from the village to the metropoli$\tan$ cities. The first phase of their accommodation is usually in the squatter areas or simply as pavement dwellers. It takes a few years for them to find a place or to rent out a room in the bustee. They experience a shrinkage in their housing spaces compared to their village huts. Along with the changes in space, their economic dimension also change. Bustees can be classified as mainly two different structures, (i) the rental houses, which are most common and predominant, and (ii) the rental "mess" units (or single person cheap lodging). The tenants range from the very poor to the lower-middle income earner. While the rented houses are taken by poor families, the mess units accommodate numerous single men, particularly the rickshaw pullers and small hawkers (Islam, 1983). Since most of the land, especially in the fringes of metropolitan Dhaka, is low and liable to annual flooding, the individual household, which buys the land, also develops it, generally by earth filling. Due to financial limitations this filling may be done incrementally over many years. Housing are also done gradually. Sometimes the whole process of land and bustee development may take 10-15 years. As bustee inhabitants reside as tenants, they can hardly change the spatial organization. Space in a gecekondu can be seen as more adaptable than in bustees since most of these settlements are owner occupied and thus the type of buildings are transformed or extended according to the social or spatial needs of inhabitants. In addition, the unfair structure of residential land and housing in Dhaka becomes obvious, in that that although the poor constitute the vast majority of the population, they have access to only a very small fraction of the city's residential land (Islam, 1986).

A typical housing unit in a bustee consists of a multifunctional space (courtyard) in front. Verandas connect both indoors and outdoors and play a role as a transition space. In some bustees, water and sanitation can be seen as common spaces for the whole bustee neighborhood. Because of limited spaces in bustees, privacy is often ignored and certain private activities are done in public such as cooking, washing or bathing. The roof of these bustees is also used for drying different food and clothing. The space is 
(a)

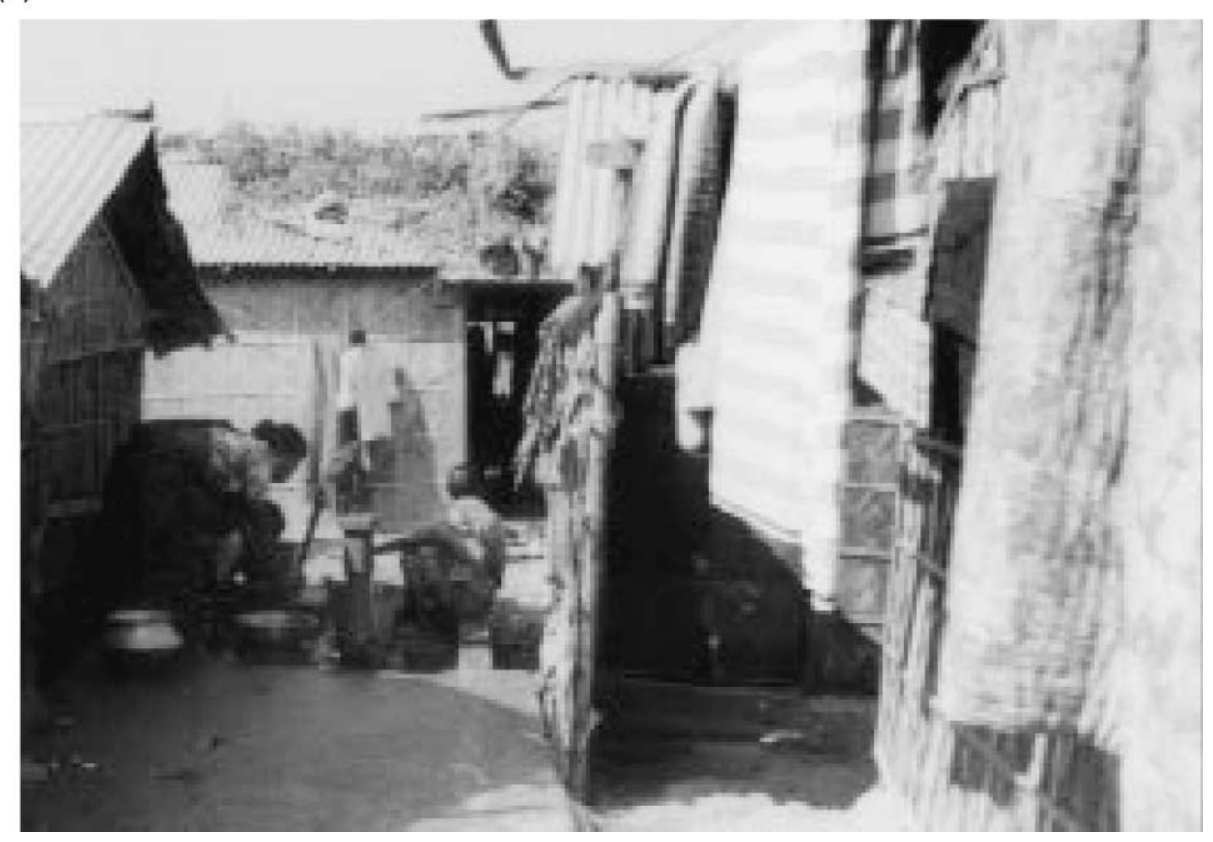

Figure 1 (a, b, c) Typical views from the bustee (Dhaka); (d) the gecekondu (Ankara)

(b)

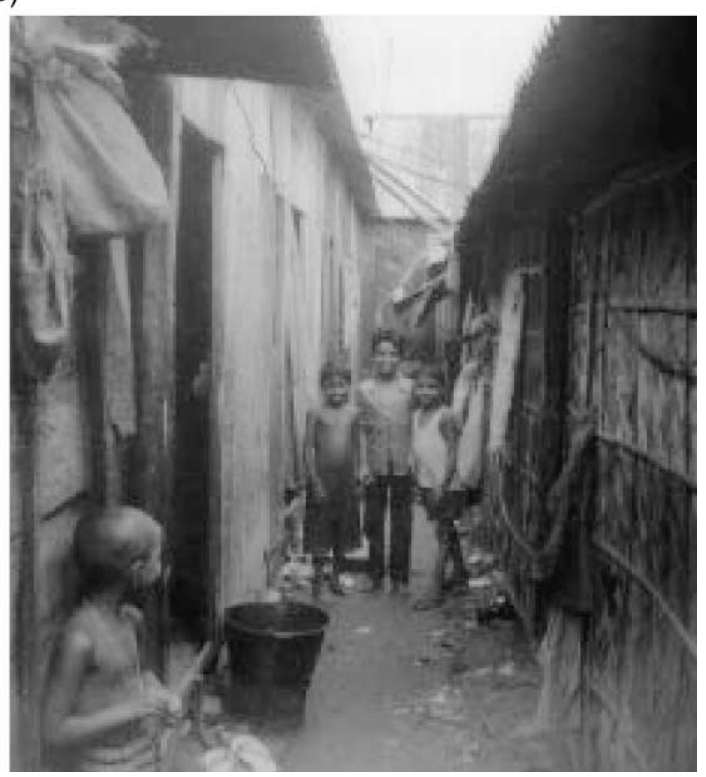

Figure 1 continued

organized spontaneously and extensions or transformations take place in the course of time, as the family gets bigger. As far as the space organizations are concerned, bustee settlements can be seen mostly as clusters. Three kinds of spaces, which can be called enclosed, semi-open and open, satisfy the separate spatial needs for different activities of a single household. Due to the limited space in bustees, paths are used for different activities as well.

Both in gecekondus and in bustees, spaces can be divided either for private or communal use. Although physical boundaries on space are not very distinct, the uses of them - especially by women - create such boundaries as private, semi-private or public spaces. It is true for both gecekondus and bus- tees that the living space in such settlement is within the domain of women. Therefore the immediate environment of the houses is not open to strangers, although they are usually open to the street. In addition, in both cases religion and tradition play an important role as many people live by the values of Islam, where the separation of sex and privacy are reflected in the physical organization of such settlements. There is a gender-based distinction in public spaces. Coffee houses belong to men in gecekondus, which are similar to tea stores in bustees. On the other hand, women can appropriate the immediate environment of the houses and move there freely although they are still under the social control of other women (Erman, 1998). The expression of "Women's place is at home" changed for the migrant women in Ankara and became "Women's place is both at home and in the neighborhood" since there exists a complete informal relation with neighbors as they share common spaces for different social activities (Kumbetoğlu, 1992). In the case of bustees, it goes one step further as women's place is at home, in the neighborhood and also at different localities, as they try to integrate with the new urban setting and involve themselves in economic activities in 
(c)

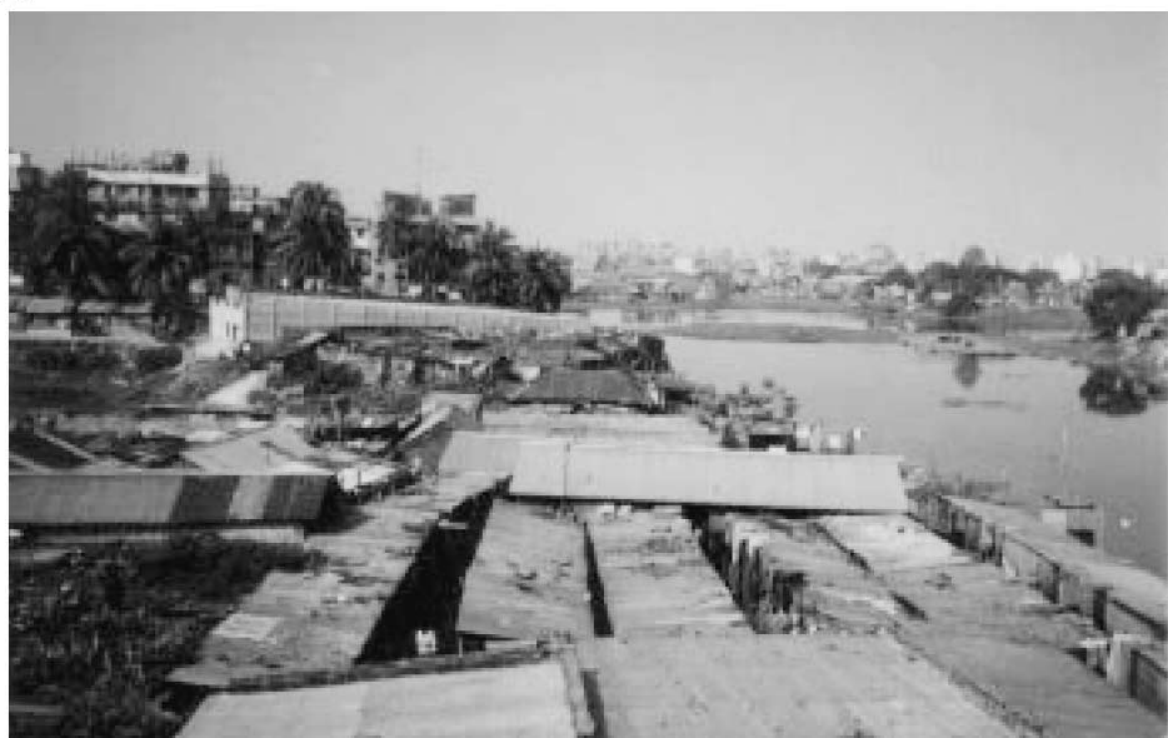

Figure 1 continued

(d)

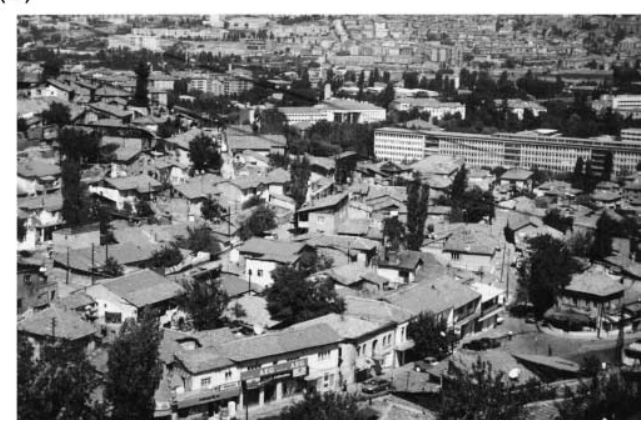

Figure 1 continued

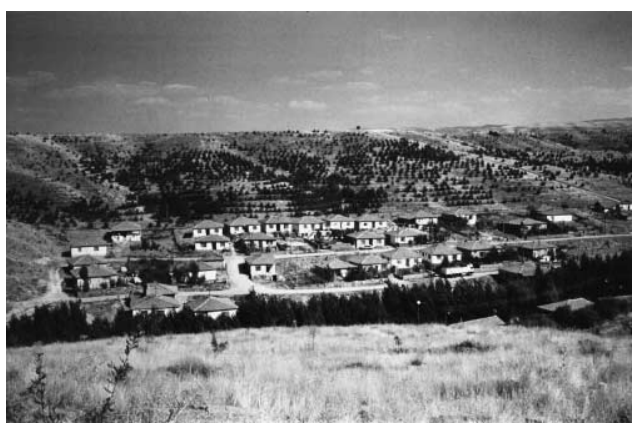

Figure 2 Aksemseddin gecekondu settlement Ankara

both formal and informal sectors.

For people in such settlements, outer space means the social and physical environment, which they share with relatives, neighbors, and close friends. In a sense, they are the extensions of houses. Here women carry out various household duties. The common spaces between houses belong to women where they gather informally, sharing local news or the concerns and tasks of daily life (Erman, 1998). Kumbetoğlu (1992) pointed out that the garden plays an important role in gecekondus as they are open to the neighborhood in which women carry out most of their work.
They produce food for family consumption or sale in the market. The garden has another important function in that it provides a living space and the only space for entertainment and leisure.

In the case of bustees, because of the space limitation such dwellers also perform most of their daily activities outdoors. Instead of the garden, the courtyard can be seen as a multi-purpose space, especially in the fringe areas. In the inner district where outdoor spaces within the households are limited, people occupy and use the path as part of their living spaces. It may be asked why people of both settlements like to perform their daily activities outdoors? Is it because they have a lack of adequate indoor spaces or because they still like to continue their tradition as a part of their culture? The issues of culture, tradition, ritual, social, political and economic conditions similarly effect the spatial organization in both cases, although the physical manifestations and characteristics differ widely.

\section{Transformation and extension possibilities of the settlements}

Although the physical appearance of the gecekondu and the bustee are different, transformations or self-initiated 
extensions are common phenomena in both. Usually, transformations take place slowly and the degree of such changes depend on the security of tenure and the ratio of owner-occupancy in the neighborhood. For gecekondus the extensions are done on a more permanent basis as most of such dwellings are owner occupied, whereas very temporary extensions can be seen in bustees as most of such inhabitants are tenants and they don't have rights to extend or transform. ${ }^{9}$ Tipple and Ameen (1999) supported such processes of extension and transformation in the low income housing as an upgrading activity. They help to improve living conditions without public support; create more room within the limited space; and also provide spaces for home-based enterprises as a source of income generation (Sinai, 1998).

In addition to the typical consolidation and extension processes in gece$k o n d u$ areas, there are very important interventions with consequential effects on the phenomenon in Turkey. Those are the amnesty laws and improvement plans from $1984 .{ }^{10}$ During the periods of electioneering, there is always an amnesty proposed for new gecekondus. By means of these Improvement Plans, the gecekondu areas are transformed into objects for land speculation because of the high building codes applied there. A transformation process of gecekondu settlements into regular apartment-house areas — so called "built-and-sell" method - was foreseen by the contractors with small capital investment in those areas by building according to the new codes. These improvement plans made in the 1980s raised hopes and expectations about the redevelopment of these settlements. In some gecekondus which were close to prestigious housing areas of the city, this process of transformation has functioned very well. A rapid development

\footnotetext{
${ }^{9}$ In Dhaka, several studies shows that these processes of extension and transformation mainly take place in low class public housing and in resettlement camps provided by the government since the control of such dwellings is loose and the dwellers believe that they won't be evicted easily.

${ }^{10} \mathrm{~A}$ detailed list of several amnesty laws can be found in TMMOB Sehir Plancilari Odasi et al (1997).
}

can be observed. However, in some other areas there is a decay in the existing structure and no new investments, because the inhabitants do not invest in their houses due to the expectations for transformation. However there exists no potential to attract the interests of investors or builders (Fig. 3).

For bustees, transformation and extension take place in two different dimensions. Owner occupier bustee dwellers make self-initiated extensions when the family gets bigger and when they are in need of more space. Moreover, some parts of the bustees are sometimes transformed into small shops or income-generated enterprises. A survey done by Tipple and Ameen (1999) showed that extensions are usually done in public housing or in resettlement camps where controls are loose. The tenant in a bustee may not have the right to make permanent changes without the permission of the owner. Transformation on the other hand is attractive for bustee owners who want to make multi-story high-rise apartments by clearing the existing temporary bustees. Opportunities for the poor to find land on which to house themselves are becoming scarcer. Entry into bustees is getting extremely difficult since these are fully occupied. The latest trend is the real estate developer who buys bustee land or marginal land in the central areas and builds multistory apartments for the upper income groups (Yasmin, 1988). The poor living in the fringe areas of the city are also threatened. Now even these locations are becoming inaccessible to them as the large real estate developers have extended their commercial interests to these areas.

\section{Conclusion}

This paper has been constructed on five basic issues, which are the location of the settlements in the city, appropriation of land and ownership patterns, economic possibilities for the inhabitants, formation and use of space and lastly transformations in these settlements. It is argued that the emergence of these settlements and formation of their spatial structure mainly depends on some similar factors, which are central for both cases, although they lead to other results or spatial manifestations in the end.

Ankara's gecekondus and Dhaka's bustees are complex and also unique settlements in their contribution to dealing with tremendous housing deficiencies in two Third World capitals. Both settlements have different physical appearances and consequences. As far as the uses of space is concerned, a gecekondu house may have more open space than a middle income household in the urban area in some Turkish cities, whereas, bustee dwellers pay more rent than any middle class family if the amount of rented floor space is considered.

In the gecekondu, squatting on unauthorized land and making shelter give an assurance for such dwellers to be landowners in future and also give freedom to mould the physical shape as they require. Both settlements are the only housing supply for the urban poor who are unable to integrate into the formal housing market, in both countries. However they are both the result of an informal housing market. Unlike gecekondu dwellers, bustee dwellers are mostly tenants who have less freedom in shaping the physical setting. Moreover, the tenancy is often totally uncertain and the residents, particularly of illegal bustees, are under constant threat of being evicted from their present site, so they remain as very temporary structures (in contrast to the gecekondu). It is obvious that owner occupancy is the primary factor in organizing space in such settlements. The security of tenure brings stability and raises the quality of the constructions. But owners, especially if they do not live there and only rent housing units, look for speculative gains and try to maximize their profit. This is very crucial in its policy implications.

Of course, different climatic conditions and everyday habits influence the physical characteristics of respective settlements, as well as economic aspects. Cultural backgrounds, social and kin relationships, and religious beliefs are also inevitable issues. Despite the similarities and dissimilarities, the emergence and the negotiation for existence in these settlements have a very similar basis. Although gecekondus and bustees are illegal, and under public threat, they are both possi- 
(a)

(b)
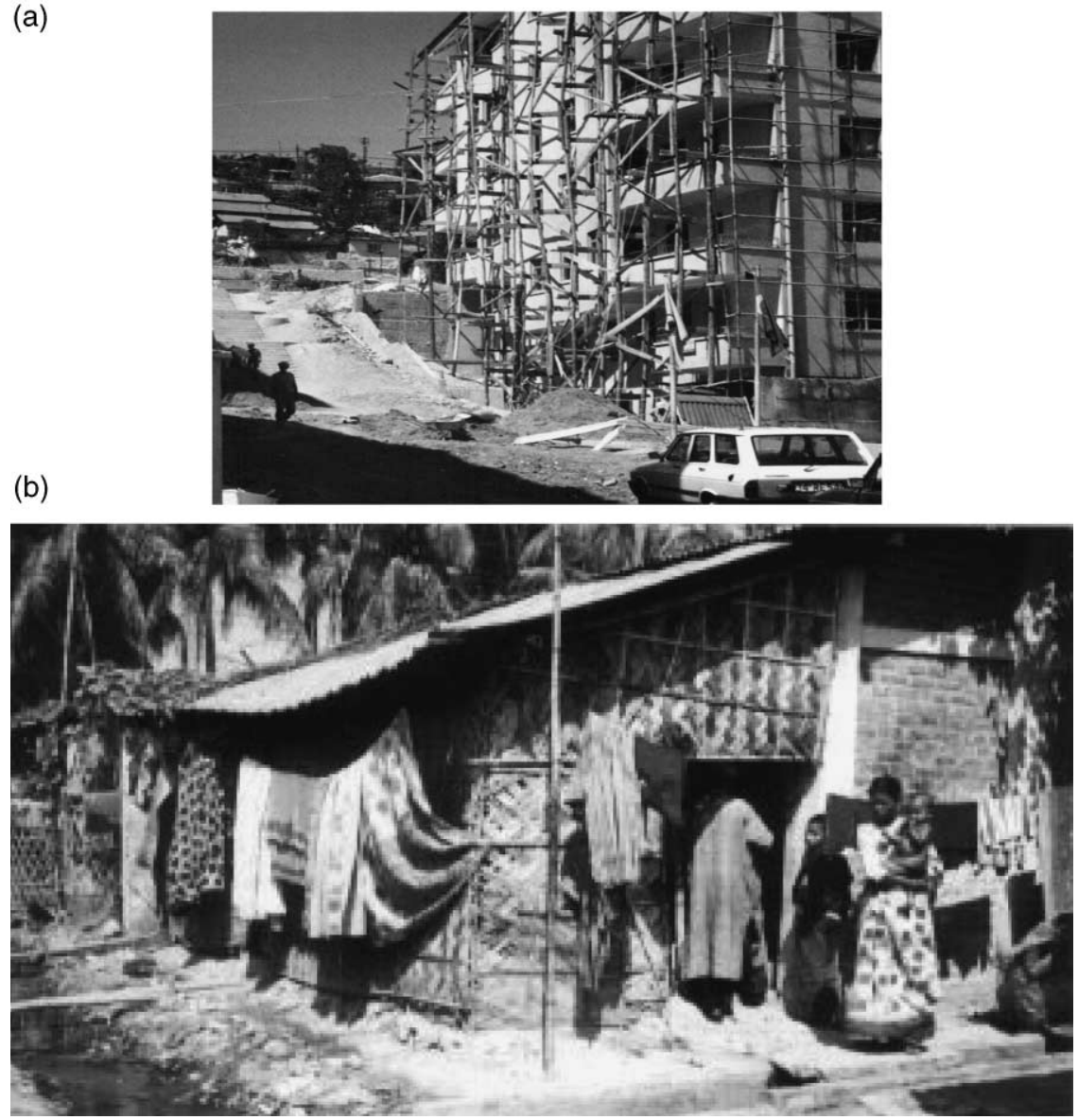

Figure 3 (a) Transformation of the gecekondu into an apartment building; (b) a bustee extension

bilities for the urban poor to support themselves in the city in terms of housing and other necessities. They live in a physical and social environment which helps them to survive and to integrate into urban life and its economy. The policies towards these settlements must not break these networks but enforce and regularize them.

Another common issue is the trend of speculation in both settlements. The whole appropriation and construction process is not only commercialized but also subject to speculation by means of exploitation of building rights and redevelopments. As a result of such a trend it becomes more difficult for the poor to have access to urban land and any accommodation in the city. It is an obvious mistake if the amnesty laws, redevelopment plans or resettlement projects ignore the necessities and possibilities of the urban poor and only support land speculation.

\section{References}

Alpar, I and Yener, S (1993) Gecekondu Arastirmasi (first published in 1991). State Planning Organization, Ankara.

Baydar Nalbantoglu, G (1998) Sessiz Direnisler ya da Kirsal Türkiye ile Mimari Yüzlesmeler. In Türkiye'de Modernlesme ve Ulusal Kimlik, S Bozdogan and R Kasaba (eds)., pp 153-167. Tarih Vakfi Yurt Yayinlari, Istanbul.

Eraydin, A and Erendil, A (1999) The role of female labor in industrial restructuring: new production process and labor market relations in the Istanbul clothing industry. Gender, Place and Culture 6(3), 259-272.

Erman, T (1998) Semi-public/semi-private spaces in the experience of turkish migrant women in a squatter settlement, Ankara. Migration und öffentlicher Raum 40-49.

Gono Shahajjo Shansta (1995) Dhaka Mahanagari Bustee. Education and Cultural Institute, Dhaka.

Gürcinar, Y (1988) Beitraege zur Milderung des Wohnungsproblems in der Türkei: für Selbstbaugeeignete Bauweisen unter Berücksichtigung der lokalen
Ressourcen, am Beispiel Ankara. Universitaet, Stuttgart.

Haque, S (1989) Residential Circumstances of Low Income Earning Single Working Women in Dhaka City. Unpublished M.Sc. thesis, Department of Geography, Dhaka University, Dhaka.

Huq-Hussain, S (1996) Female migrants in an urban setting - the dimension of spatial/physical adaptation: case of Dhaka. Habitat International 20(1), 93-107.

Islam, S (1983) Pattern and Process of Mess Housing in Dhaka City. Unpublished Master's thesis, Department of Geography, University of Dhaka.

Islam, N (1986) Poor access to residential space in an unfairly structured city, Dhaka. Oriental Geographer 29-30.

Islam, N (1996) Dhaka: From City to Megacity. Dana Printers Ltd, Dhaka.

Islam, N, Nazem, N and Mahbub, A (1996) CUS survey of slums and squatter settlements in Dhaka City: summary findings. CUS Bulletin 31, 8-10.

Kumbetoğlu, B (1992) Women's Informal Sector Contribution to Survival of their Household in Urban Turkey. Marmara University, Sos. Bil. Enst. Unpublished $\mathrm{PhD}$ thesis, Istanbul. 
Leitmann, J and Baharoglu (1999) Reaching Turkey's spontaneous settlements: the institutional dimension of infrastructure provision. International Planning Studies 4(2), 195-212.

McTaggart, W D (1988) Geographic perspective on spontaneous shelter. In Spontaneous Shelter, C V Patton (ed.). Temple University Press, Philadelphia.

MOL/GOB (1989) Report of the Dhaka Mahanagari Bustee Samasya Niroshan Committee. City Slum Problem Redressal Committee, Dhaka.

Özdemir, N (1998) The Transformation of Squatter Settlements into Authorized Apartment Blocks: A Case Study of Ankara, Turkey. Thesis submitted in part fulfillment for the degree of Doctor of
Philosophy at the University of Kent at Canterbury.

Payne, G K (1982) Self-help housing: a critique of gecekondus of Ankara. In SelfHelp Housing - A Critique, P Ward (ed.). Mansell Publishing Limited, London.

Rahman, M M (1999) Squatters and housing rights. The Daily Star, Dhaka, 24 September, p. 7.

Sinai, I (1998) Using the home for income generation: the case of Kumasi, Ghana. Cities 15(6), 417-427.

Senyapili, T (1983) A new component in metropolitan areas: the gecekondu women. In Women in Turkish Society. Nermin Abonden-Unat, Leiden.

Tekeli, I (1996) Türkiye'de Yasamda ve
Yazinda Konut Sorunun Gelisimi. Konut Arastirmalari Dizisi. TOKI, Ankara.

Tipple, G and Ameen, S (1999) User initiated extension activity in Bangladesh: "building slums" or area improvement? Environment and Urbanization 11(1), 367-376.

TMMOB Sehir Plancilari Odasi, UNDP, Yenimahalle Belediyesi, TOKI (1997) Gecekondu Ulusal Fikir Yarismasi Jüri Üyelerine Sunulmak Üzere Rapor. Ankara.

Yasmin, M (1988) Land Pooling Techniques in Urban Fringe land development of Dhaka City. Unpublished Master's thesis, AIT, Bangkok.

White, J B (1996) Family industry in Istanbul: labor and social identity. Trialog 49 , 32-36. 